\title{
Emotional Intelligence and Project Success: The Roles of Transformational Leadership and Organizational Commitment
}

\author{
Thuy Thanh Thi DOAN*, Linh Cam Tran NGUYEN**, Thanh Dan Ngoc NGUYEN*** \\ Received: January 06, 2020 Revised: February 03, 2020 Accepted: February 06, 2020.
}

\begin{abstract}
The paper aims to examine the relationship of emotional intelligence on the project success, the causal relationship between emotional intelligence and project success, and also investigate the influence of emotional intelligence and the mediating role of transformational leadership as well as the moderating effect of organization commitment on the relationship between emotional intelligence and project success. Cross sessional research is applied to collect the data in this study. By applying quantitative research and survey question, the study collects 325 respondents who are the project managers. Snow-ball sampling method is used to distribute the questionnaires by face to face survey (68\% of respondents) and online survey (32\% of respondents). The collected data is analyzing by applying partial least square (PLS-SEM) via software SmartPLS 3.0.The result shows that the emotional intelligence and the transformational leadership making the project even more successful as the mediation actor. Furthermore, the project commitment also has the moderator effect between transformational leadership and project success. With the result of study, project managers should be aware of the importance of emotional intelligence and their commitment to the ability to manage projects successfully. A successful project is a combination of many actors, the most critical actor is the leader of the project.
\end{abstract}

Keywords: Emotional Intelligence, Organization Commitment, Project Success, Transformational Leadership

JEL Classification Code: M10, M19,O22

\section{Introduction}

Leadership is an essential component in defining the project success (Dvir, Lipovetsky, Lechler, Shenhar, \& Tishler, 2002). Leadership style is a form of leadership behavior that affects the activities of others and is considered an important management element. There are different types of leadership styles such as transformational, transactional and laissez faire, but the preferred style of leadership in the organizational environment is the transformational leadership style (Barling, 2014), especially for project-oriented organizations (Gundersen, Hellesøy, \&

*First Author. Lecturer, Faculty of Business Administration, Ho Chi Minh City Open University, Vietnam. Email: thuy.dtth@ou.edu.vn ${ }^{* *}$ Corresponding Author. Lecturer, Faculty of Business Administration, Ho Chi Minh City Open University, VietNam [Postal Address: Room 403, 35-37 Ho Hao Hon Street, Co Giang Ward, District 1, Ho Chi Minh City, 700000, Vietnam] Tel: +84937978398. Email: linh.ntc@ou.edu.vn ***Lecturer, Faculty of Business Administration, Ho Chi Minh City Open University, Vietnam. Email: thanh.nnd@ou.edu.vn

() Copyright: The Author(s)

This is an Open Access article distributed under the terms of the Creative Commons Attribution NonCommercial License (https://creativecommons.org/licenses/by-nc/4.0/) which permits unrestricted noncommercial use, distribution, and reproduction in any medium, provided the original work is properly cited.
Raeder, 2012). This is a leadership style that can convey positive inspiration to their followers (Sohmen, 2013). The leadership style of transformational has a great impact on the project success (Huang, Wu, \& Yang, 2011) and is conformable for any type of project (Dulewicz\& Higgs, 2005).

While considering the relationship between the transformational leadership and the success of the project, the project manager's commitment is also a potential factor that can lead to different project implementation results. The performance of profitable organizations is influenced by management commitment (Kaplan \& Norton, 2007). The commitment of top managers is an important success factor in the project planning phase (Fowler \& Horan, 2007). Committed project managers are able to make a positive change in the project through monitoring the development and ensuring the project's available resources, which in turn can lead to successful project management (Pinto \& Prescott, 1988).

Numerous studies have explored the relationship between transformational leadership and project success (e.g., Iqbal, Khan, \& Sang, 2015; Frimpong, Hongyi, \& Nubuor, 2014), and the known effect of the commitment to project outcomes (Korzaan, 2009; Ghazinejad, Hussein, \& 
Zidane, 2018; Pham, Nguyen, Tu, Pham, \& Le, 2019). However, there is no evidence yet on the moderation role of project managers' commitment to project success. Therefore, to take one more step, our first goal is to explore the moderating role of project managers' organizational commitment from transformational leadership and project success.

Tranformational leadership behaviors are more likely to be expressed by individuals with emotional intelligence (Barling, Kelloway, \& Slater, 2000). Emotional intelligence is the main element responsible for transformational leadership styles and can be used as a predictive tool for transformational leadership styles (Barbuto \& Burbach, 2006). Emotional intelligence is a remarkable predictor of efficiency and success in one's work (Butler, 2005; Goleman, 1996).High emotional intelligence can help project managers resolve new challenges and problems from a different perspective than authoritarian managers (Ashkanasy, Chang, Mazur, \& Pisarski, 2014).

Although previous studies have affirmed emotional intelligence as a success factor in project management and an important and necessary competency for project managers (Jovanovic, Mihic, Mitrovic, Obradovic, \& Petrovic, 2013; Rezvani, 2016; Asare, 2016). However, up to now, there have been very few studies evaluating the relationship between emotional intelligence and the project success by the mediation model.Hence, with the above arguments, we recommends transformational leadership as a mediatorfor the second research objective. The potential mediating role of transformational leadership in the relationship between emotional intelligence and project success has not been addressed in previous researches.

By addressing the two research goals mentioned above, in this study, we contribute to literature in three ways. Firstly, this is one of the first studies examining the complex relationship of emotional intelligence on the project success. Secondly, more importantly, this is the first study to clearly identify the mediating role of transformational leadership in the relationship between emotional intelligence and project success.Thirdly, this study enhances our understanding of the moderating role of project managers' commitment. We argue that the impact of transformational leadership on project success will be stronger when project managers are committed to the projects they manage.

Moreover, emotional intelligence is a type of capacity that can be learned and enhanced, so our research also provides some implications for project management practices. First, project managers should be aware of the importance of emotional intelligence to the ability to manage projects successfully, thereby seeking to improve and enhance the various dimensions of emotional intelligence, because an increase in emotional intelligence will likely enhance project management capabilities. Second, project-oriented organizations when recruiting personnel to be project managers should be concerned with emotionally intelligent candidates, and also explore ways of training or policies to develop and enhance the emotional intelligence as well as the commitment of project managers in order to help them become more outstanding.

\section{Literature Review}

\subsection{Project Success}

Traditionally, cost, time and quality are the three basic criteria for project success. However, these trio are increasingly exposed to many shortcomings (Angus, Bowers, \& Flett, 2005) and are thought to be inadequate to measure the success of a project as long as the project requires quality in the project management process and satisfies the requirements of stakeholders (Bakhsheshi \& Nejad, 2011). Baccarini (1999) and Pinto and Slevin (1987) suggested that projects considered successful have to add customer satisfaction criteria and benefit a specific customer group. According to Chan (2001), successful projects should meet the following criteria: time; cost; technical requirements; satisfaction of stakeholders; end user expectations; the surrounding environment; business value and safety during construction. Based on many previous studies on project success (e.g., Bryde, 2008; Dvir, Malach-Pines, \& Sadeh, 2006; Jugdev \& Muller, 2005; Dvir, Levy, Maltz, \& Shenhar, 2001; Aouad, El-Saboni, \& Sabouni, 2009 ; Muller \& Jugdev, 2012; Müller \& Turner, 2007; Stefanovic, 2008), Mir and Pinnington (2014) argue that the success of a project should be evaluated against the short-term and long-term goals of the project, including factors related to: (1) the effectiveness of the project; (2) influence on customers; (3) business success; (4) affecting the future; and (5) teamwork effectiveness.

\subsection{Emotional Intelligence}

Mayer and Salovey (1997) proposed emotional intelligence as a combination of four groups of emotionrelated competencies, from basic skills to complex skills, specifically described as follows: (1) Self Emotional Appraisal (SEA): an individual's capacity to feel, understand and express his/her own emotions;(2) Others Emotional Appraisal (OEA): an individual's capacity to identify the emotions of those around him/her by observing the feelings of others;(3) Regulation Of Emotions (ROE): an individual's capacity to regulate and control emotions within each individual and act to help or facilitate emotions in others;and (4) Use Of Emotions (UOE): an individual's 
capacity to regulate his emotions towards more constructive and effective activities.

\subsection{Emotional Intelligence and Project Success}

In projects, managers with emotional intelligence approach management responsibilities from a different perspective than authoritarian managers (Asare, 2016). The project's failure rate in the world is still very high and it is surprising that the knowledge or know-how of leadership is not the main cause, but the project manager lacks social intelligence and skills such as communication or conflict resolution (Srica, 2008). Müller and Turner (2010) have shown that emotional intelligence abilities are related to the way work is performed and the emotional intelligence plays a key role in improving the performance of project managers. Furthermore, high emotional intelligence can allow project managers to strongly inspire project team members, create motivation to work and increase commitment of members to the project (Clarke, 2010). Thus, we recommend the first research hypothesis:

Hypothesis 1: Emotional Intelligencehave a positive impact on project success.

\subsection{Transformational Leadership}

Initially, transformational leadership consisted of three components: individual consideration, idealized influence and intellectual stimulation (Bass, 1985). Avolio and Bass (1994) added the "inspirational motivation" component to transformational leadership theory. Specifically, these 4 components of transformational leadership are: (1) Idealized Influence (II): Leaders inspire trust and pride in their employees through their actions and direct their employees to the common interests of the collective and other members rather than the interests of the individual; (2) Inspirational Motivation (IM): Leaders always motivate employees by showing them the meaning and challenges of their job;(3) Intellectual Stimulation (IS): Leaders stimulate employees' efforts in the direction of innovation and creativity; and (4) Individualized Consideration (IC): Leaders pay special attention to the development of each employee by activities such as training or counseling.

When investigating traits that make an individual more likely to accept and implement the type of transformational leadership, many studies have suggested that one of them is emotional intelligence (Barling et al., 2000; Butler, 2005; Goleman, 1996). In the project, the appropriate behavior of project managers is very important in leading the project to success (Balogun \& Johnson, 2004; Lara, 2011). Project managers with transformational leadership behaviors are more likely to achieve success when managing projects
(Huang, Wu, \& Yang, 2011).

Transformational leaders always make members aware of their specific role and the standards that need to be met for the project, and explain the overall picture of the project so every project member can imagine (Gundersen et al., 2012; Suong, Thanh, \& Dao, 2019). They always promote healthy relationships at work (Sohmen, 2013), strengthen solidarity among team members as well as facilitate open exchange of ideas and views among project teams. According to the studies of Aga, Noorderhaven and Vallejo (2016); and Khanzada and Naeem (2017), the leadership style of project managers plays a key role in project success. A transformational leadership project manager who can inspire team members to work together to achieve project success, both on the effectiveness of the project and the satisfaction of the stakeholders (Lee, 2018).

Based on the above arguments, it seems reasonable for us to hope that emotional intelligence enhances the transformational leadership behavior, thereby positively impacting the effectiveness of the project. Therefore, transformational leadership can be suggested to play a mediating role in the relationship between emotional intelligence and project success. This link is necessary to investigate, because this potential mediating role of transformational leadership in the relationship between emotional intelligence and project success has not been tested in previous studies. Hence, we recommend the following:

Hypothesis 2: Transformational leadership mediates the relationship between emotional intelligence and project success.

\subsection{Project Managers' Organizational Commitment}

Organizational commitment is defined in this study as the power of identity between an individual and an organization.An individual with a high level of commitment to an organization is more satisfied with his/her job and less likely to leave his/her job and organization (Mowday, Porter, \& Steers, 1979). According to this definition, organizational commitment involves three elements: (1) Identification (Ide): the individual has a strong belief in and accepts the organization's goals and values, or in other words, individual's goals are alsoorganizational goals; (2) Involvement (Inv): the individual efforts for the development and goals of the organization; (3) Loyalty (Loy): the individual always wants to remain a member of the organization. Therefore, a person, whether a manager or an employee, can be committed to the project on all three.

Manager's commitment has been found to affect the performance of all profitable organizations (Kaplan \& 
Norton 2007). The commitment of top managers increases trust with employees and their organization is therefore better (Ndiritu, 2015). The stronger the commitment of the leaders, the more likely the members are to work harder to accomplish the organization's goals (Caroline, Harriet, \& Anne, 2016). A transformational leader who has an organizational commitment is capable of shaping and nurturing a corporate culture where every member is committed and loyal and proud of their organization (Kouze \&Posner, 2002), and ensure that every effort is directed towards quality and customer orientation (Caroline et al., 2016).

In a project, one of the drivers of failure is lack of commitment (Avots, 1969). Commitment leads to efforts in bringing the project to completion, especially when there are obstacles to the project (Mowday et al., 1979). Commitment also plays an important role in reducing costs and project progress issues (Arshad, Ehsan, Gulzar, Hafeez, \& Mirza, 2012). In addition, Andersen, Arne Jessen, Birchall, and Money (2006), when researching on various projects of type and scale, concluded that project commitment positively affects project success in both project objectives, time and budget. In general, commitment has a positive link to project performance (Erez, Locke, \& Latham, 1988).

We expect that transformational leaders who are highly committed will always care about the effectiveness of the project and stay engaged with the project. This increases the confidence of the project being implemented not only to the manager but also to all project members, thereby affecting project efficiency. Therefore, we state the following hypothesis, and if supported, this will be the first relationship examined by our study:

Hypothesis 3: Project Managers' Organizational Commitment moderates the strength of the mediated relationship between emotional intelligence and project success through transformational leadership.

\subsection{Proposed Research Model}

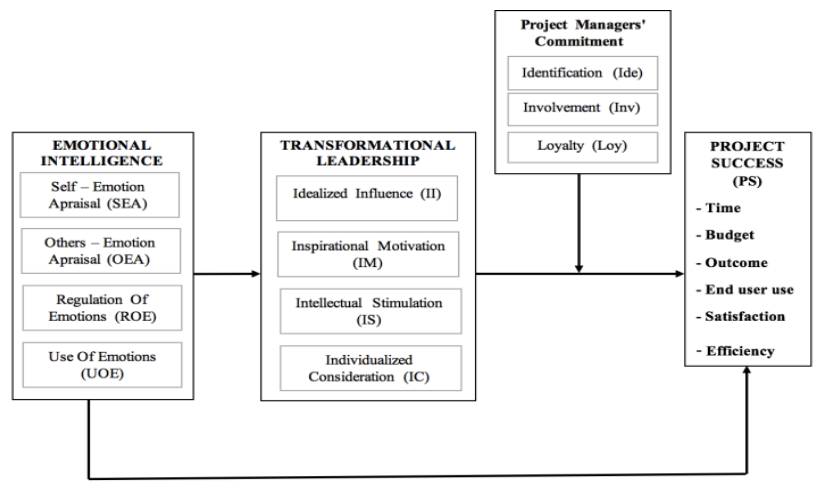

Figure 1: The proposed research model
Based on the theoretical foundations and previous studies that were discussed above, we developed the following research model (see Figure 1).

\section{Research Methods}

\subsection{Measures}

Based on the project manager 's understanding of the project' s success criteria, the scale used in this study is a multi-dimensional structured scale related to the project success and is evaluated by the project managers on the Likert scale. The use of this scale is consistent with previous studies such as Bryde (2008); Khang and Moe (2008); Mir and Pinnington (2014); Bakker, Mooi and Suprapto (2015); Aga et al. (2016), in which project success is measured by 14 items on the Likert scale ranging from 'strongly disagree' to 'strongly agree', relating to time, budget, outcome, end user use, satisfaction and efficiency.

While researching on transformational leadership, researchers often use the MLQ (Multifactor Leadership Questionnaire) scale which was originally proposed by Bass (1985). Further studies on measurement of transformational leadership are also based on this first version. In this study, we inherit the scale of transformational leadership from Aga et al. (2016), this scale consists of 13 questions measuring transformational leadership and has been tested to have a higher Cronbach's alphas compared to previous studies and anchored from 'strongly disagree' and 'strongly agree' on Likert scale.

The emotional intelligence scale used in this study is the Wong and Law Emotional Intelligence Scale (WLEIS, Law\&Wong, 2002). This scale consists of 16 questions that are assessed for 4 dimensions of emotion, namely: Self Emotional Appraisal (SEA), Others Emotional Appraisal (OEA), Regulation Of Emotions (ROE) and Use Of Emotions (UOE). Each dimension consists of 4 questions rated on a Likert scale from 'strongly disagree' to 'strongly agree'.

To measure the project manager 's organizational commitment in this study, we used the organizational commitment scale developed by Mowday et al. (1979). The scale consists of 15 items with each dimension measured by 5 items. Each item is rated on a five-point Likert scale from 'strongly disagree' to 'strongly agree'.

\subsection{Sampling}

This study aimed to investigate the mediating role of Transformational leadership toward the link with Emotional intelligent of project managers to project success and the moderating role of Project commitment toward the link of 
Transformational leadership and Project success of project managers in Vietnam. Hence this study focused on project managers who already managed at least one project in his/her company. Cross sessional research is applied to collect the data in this study. We distributed 500 questionnaires to companies and 325 project managers sent the feedback. Snow-ball sampling method is used to distribute the questionnaires by face to face survey $(68 \%$ of respondents) and online survey (32\% of respondents).

This research focused on mediating and moderating paths in the research model therefore, collected data is analyzing by applying partial least square (PLS-SEM) via software SmartPLS 3.0 in order to investigate the mediation effect of Transformational leadership and moderation effect of Project commitment toward Project success.

\subsection{Respondent Profile}

Man project managers is contained $77.2 \%$ and women is much less than man which is contained $22.8 \%$. Most of project managers in this study has the aged ranged from 3645 years old $(42.5 \%)$, the second age-range is older than 55 years old which is contained $25.5 \%$. There are $72.6 \%$ interviewee graduated from University and the rest of project leaders finished their master program. $52 \%$ of the project leaders who answered the interview have been working in project management more than 5 years, $13.5 \%$ who has 2-3 years experiencing and about $9.5 \%$ project leaders have 4-5 years working in this field. $39 \%$ project leader in this research is working for construction field, $8 \%$ is working for environment project, $10.2 \%$ is belonged to M\&E Project, $8.3 \%$ is managing IT project, and $36.6 \%$ is working for other projects. The projects which involve in our study have been running for 32\% 50-100 employee- company, $30.8 \%$ company which has less than 50 employees, $16 \%$ company which has 100-200 employees and $9.5 \%$ company which has $200-300$ employees, there is only $3.7 \%$ company which has over than 300 employees joining this study.

\section{Results}

\subsection{Convergent Validity, Discriminant Validity, and Composite Reliability}

The results proved that all of constructs satisfied the reliability requirements, Dijkstra-Henseler's rho (rho_A) index is ranged from 0.620 to 0.867 . There are two constructs which has unsatisfied rho_A index (IC and II), the rest of constructs have greater rho_A value which satisfied the requirement. The reason of using rho_A instead of Cronbach's alpha is this index indicated the consistency and accurate calculation which showed the internal items are reliable (Hair, Hult, Ringle, \& Sarstedt, 2017). Composite reliability of all constructs was ranged from 0.7 to 0.907 and greater than 0.7 , which were satisfactory good (Hair, Risher, Sarstedt, \& Ringle, 2019).

AVE of all constructs were ranged from 0.52 to 0.72 (except two constructs Inv and Ide) indicating that convergent validity was supported (Henseler, Hubona, \& Ray, 2016; Henseler, 2017). In order to test the discriminant validity, we used two methods (1) discriminant validity index recommended by Fornel and Lacker (1981), (2) Heterotrait-monotrait (HTMT) ratio recommended by Henseler, Ringle, and Sarstedt (2015) and Voorhees et al. No Reference (2016).

Table 1: Discriminant testing results

\begin{tabular}{|c|c|c|c|c|c|c|c|c|c|c|c|c|}
\hline & Inv & IC & II & IM & IS & Loy & OEA & Ide & PS & ROE & SEA & UOE \\
\hline Inv & 0.6 & & & & & & & & & & & \\
\hline IC & 0.5 & 0.8 & & & & & & & & & & \\
\hline II & 0.4 & 0.3 & 0.8 & & & & & & & & & \\
\hline IM & 0.6 & 0.6 & 0.6 & 0.7 & & & & & & & & \\
\hline IS & 0.5 & 0.6 & 0.5 & 0.7 & 0.7 & & & & & & & \\
\hline Loy & 0.3 & 0.2 & 0.1 & 0.3 & 0.3 & 0.7 & & & & & & \\
\hline OEA & 0.5 & 0.5 & 0.4 & 0.5 & 0.4 & 0.1 & 0.8 & & & & & \\
\hline Ide & 0.6 & 0.4 & 0.5 & 0.6 & 0.5 & 0.3 & 0.4 & 0.6 & & & & \\
\hline PS & 0.5 & 0.5 & 0.5 & 0.6 & 0.6 & 0.3 & 0.5 & 0.5 & 0.7 & & & \\
\hline ROE & 0.4 & 0.4 & 0.5 & 0.6 & 0.6 & 0.3 & 0.4 & 0.4 & 0.6 & 0.8 & & \\
\hline SEA & 0.5 & 0.5 & 0.5 & 0.5 & 0.5 & 0.1 & 0.6 & 0.5 & 0.6 & 0.5 & 0.8 & \\
\hline UOE & 0.5 & 0.4 & 0.4 & 0.6 & 0.5 & 0.4 & 0.4 & 0.5 & 0.5 & 0.5 & 0.4 & 0.7 \\
\hline
\end{tabular}


Table 1 showed traditional metric of discriminant validity testing recommended by Fornel and Lacker (1981) are satisfied cause the square root AVE (ranged from 0.638 to 0.866) of all constructs are greater than square internalconstruct correlation. HTMT ratio is ranged from 0.190 to 0.85 which showed the qualified index to satisfy the discriminant validity (Nitzl, 2016; Henseler et al., 2015). According to Bentler and $\mathrm{Hu}$ (1999), the goodness-of-fit (GoF) was tested based on SRMR criteria. The result showed that SRMR is 0.073 which is lower than 0.08 threshold indicated the good fit model (Hair et al., 2019). R2 of three constructs IM, IS, PS are greater than 0.5 which indicated the moderate model's predictive accuracy and the rest two constructs has $\mathrm{R} 2$ value in between 0.5 and 0.25 which indicated the weak model's predictive accuracy (Henseler et al., 2009).

\subsection{Structural Model Results}

Table 2 showed three sub-constructs of Emotional Intelligent latent variable (UOE, ROE and SEA) have positively impact on Project success $(\beta=0.198, p=0.000$ for UOE, $\beta=0.248, p=0.000$ for ROE, $\beta=0.327, p=$ 0.000 for SEA) while the rest sub-construct of Emotional Intelligent which is OEA is not supported to positively impact on project success.

Table 2: Hypothesis testing results

\begin{tabular}{|c|c|c|c|c|}
\hline Hypothesis 1 & Hypothesis for sub-construct & Path coefficients for direct effect & P Values & Unsupported \\
\hline \multirow{2}{*}{$\begin{array}{c}\text { Emotional Intelligence } \\
\text { have a positive impact on } \\
\text { project success. }\end{array}$} & OEA -> PS & N/A & 0.756 & $0.000^{* * *}$ \\
\cline { 2 - 5 } & UOE -> PS & 0.198 & $0.000^{* * *}$ & Supported \\
\cline { 2 - 5 } & ROE -> PS & 0.248 & $0.000^{* * *}$ & Supported \\
\hline
\end{tabular}

*** $\mathrm{P}$ value significant at level 0.005

** $\mathrm{P}$ value significant at level 0.05

$*$ P value significant at level 0.1

Table 3: Mediation effect

\begin{tabular}{|c|c|c|c|c|}
\hline Hypothesis 2 & Hypothesis for sub-construct & Path coefficients for total effect & P Values & \\
\hline \multirow{16}{*}{$\begin{array}{l}\text { Transformational } \\
\text { leadership mediates the } \\
\text { relationship between } \\
\text { emotional intelligence and } \\
\text { project success. }\end{array}$} & OEA -> IC -> PS & N/A & 0.159 & Unsupported \\
\hline & ROE -> IC $->$ PS & N/A & 0.169 & Unsupported \\
\hline & SEA $->$ IC $->$ PS & N/A & 0.197 & Unsupported \\
\hline & UOE -> IC $->$ PS & N/A & 0.130 & Unsupported \\
\hline & OEA -> II -> PS & N/A & 0.222 & Unsupported \\
\hline & ROE -> II -> PS & 0.043 & $0.042 * *$ & Supported \\
\hline & SEA -> II -> PS & N/A & 0.105 & Unsupported \\
\hline & UOE -> II -> PS & N/A & 0.205 & Unsupported \\
\hline & OEA -> IM -> PS & 0.031 & $0.057^{*}$ & Supported \\
\hline & ROE -> IM -> PS & 0.051 & $0.050 * * *$ & Supported \\
\hline & SEA -> IM -> PS & N/A & 0.277 & Unsupported \\
\hline & UOE -> IM -> PS & 0.062 & $0.022 * *$ & Supported \\
\hline & OEA -> IS -> PS & N/A & 0.206 & Unsupported \\
\hline & ROE -> IS -> PS & 0.042 & $0.069^{*}$ & Supported \\
\hline & SEA -> IS -> PS & N/A & 0.128 & Unsupported \\
\hline & UOE -> IS -> PS & 0.022 & $0.099^{*}$ & Supported \\
\hline
\end{tabular}

*** P value significant at level 0.005

$* *$ P value significant at level 0.05

* P value significant at level 0.1

Table 3 show that there are six pairs of sub-constructs of Transformational leadership and Emotional intelligent construct positively mediate the relationship between emotional intelligence and project success. They are mediating effect of (1) II toward the relationship of ROE and PS, (2) IM toward the relationship of OEA and PS, (3) IM toward the relationship of ROE and PS, (4) IM toward the relationship of UOE and PS, (5) IS toward ROE and PS 
and (6) IS toward the relationship of UOE and PS.

Table 4 show that there are four sub-constructs of Project Managers' Organizational Commitment moderates the strength of the mediated relationship between emotional intelligence and project success through transformational leadership. They are (1) Inv moderated the strength of the mediated relationship between IS and PS, (2) Inv moderated the strength of the mediated relationship between IC and PS, (3) Ide moderated the strength of the mediated relationship between IC and PS, (4) Ide moderated the strength of the mediated relationship between IS and PS.

Table 4: Moderation effect

\begin{tabular}{|c|c|c|c|c|}
\hline Hypothesis 3 & Hypothesis for sub-construct & Path coefficients & P Values & \\
\hline \multirow{12}{*}{$\begin{array}{l}\text { Project Managers' } \\
\text { Organizational } \\
\text { Commitment moderates the } \\
\text { strength of the mediated } \\
\text { relationship between } \\
\text { emotional intelligence and } \\
\text { project success through } \\
\text { transformational } \\
\text { leadership. }\end{array}$} & Inv and IS -> PS & -0.159 & $0.072 *$ & Supported \\
\hline & Inv and IC $->$ PS & 0.163 & $0.015 * *$ & Supported \\
\hline & Inv and II $->$ PS & $\mathrm{N} / \mathrm{A}$ & 0.813 & Unsupported \\
\hline & Inv and IM $->$ PS & N/A & 0.783 & Unsupported \\
\hline & Loy and IC $->$ PS & $\mathrm{N} / \mathrm{A}$ & 0.706 & Unsupported \\
\hline & Loy and II $->$ PS & N/A & 0.247 & Unsupported \\
\hline & Loy and IM $->$ PS & N/A & 0.738 & Unsupported \\
\hline & Loy and IS -> PS & $\mathrm{N} / \mathrm{A}$ & 0.716 & Unsupported \\
\hline & Ide and IC $->$ PS & -0.174 & $0.023^{* *}$ & Supported \\
\hline & Ide and II $->$ PS & N/A & 0.164 & Unsupported \\
\hline & Ide and IM -> PS & N/A & 0.236 & Unsupported \\
\hline & Ide and IS -> PS & 0.147 & $0.084 *$ & Supported \\
\hline
\end{tabular}

*** $\mathrm{P}$ value significant at level 0.005

** $\mathrm{P}$ value significant at level 0.05

* P value significant at level 0.1

\section{Discussion and Implication}

Emotional intelligence is an important antecedent in many fields, but in implementing a project as in this study context, it is more crucial in leading to an outcome of the project. If a leader has the emotional intelligence that will help their employees have the ideal working environment and produce a successful outcome. This study also proved this to be true when all second orders of emotional intelligence have positively affected project success and the highest impact comes from others-emotion appraisal. And this result is reasonable for the project leaders when their working environment is full of people, understanding the emotion of them will make the process more effectively and easily. This finding is fit with the research of Ashkanasy, Daus and Hartel (2002); and Huang and Wang (2009) which were agued components of emotional intelligence were highly consistent with transformational leadership behavior.

The transformational leadership in this article has been shown to play a role in making the project even more successful. With the mediation role between emotional intelligence and project success, it increases the impact degree to the relation. Although the results find that there is half of the second-order of transformational leadership has the role of mediating the relationship between emotional intelligence (Regulation of Emotion, Others Emotion Appraised, Use of Emotion) and project success such as: Inspirational Motivation (IM);Idealized Influences (II); Intellectual Stimulation (IS), but it also finds the meaning of transformational leadership in project implementation, and this is an indispensable element when manager has a good emotional intelligence.

In addition, the factors of Intellectual Stimulation (IS) and Individualized Consideration (IC) are negative affected by the project success with the impact of moderator variable belonging to project commitment (Identification and Involment). The fact that IC is negatively affected by the success of the project with the impact of Identification (Ide) could imply that the commitment to the project is very important, but if the pressure to complete the successful project is so high, it may make the project members feel uncomfortable. Therefore, the project managers need to understand the employees' emotion and themselves to balance their focus. On the other hand, the second orderconstruct called Involment(Inv) which reduces the impact of IS on project success can be explained that althought all incentives to employees are the things that leaders do, but sometimes encouraging too many ideas in the running project will result the unsuccessful outcome. Besides, selfappraisal has no impact on intellectual stimulation and other variables of transformational leadership, it is proving that leaders cannot catch and understand their own emotion 
to spread out the desired behaviors. This led to the project not succeeding as expected by the gap between internal emotions and external behaviors. The results fit with Cartwright and Lindebaum (2010) which stated there was no correlation between emotional intelligence and transformational leadership because of the inconsistent in explaining the leadership style beyond the personality and cognitive ability.

One of the elements of being a good leader is the ability to influence the employees by the leader's competence. The admiration of the team members to the project leader will help the project completely success and it is the results of this paper and this was found in the research of Avolio, Walumbwa, and Weber (2009), De Gilder, Ellemers, and Haslam (2004), Brown and Lord (2001). Moreover, the organization identification variable is a moderation role between the idealized influences and the project success, it is mentioned the influences of project leader should include the image of the organization they belong to make the project much more successful. Many studies such as Atwater, Carmeli, and Levi (2011), Martin and Epitropaki (2005), and Liu, Zhu, and Yang (2010) mentioned the leadership style might shape how their employees feel about their relationship and social identifications with their work organization.

In the process of the project, involvement in the project is always the most important part of the commitment of the leaders. The results of the research demonstrate that it has a negative impact on the project success. In some cases, the project leaders commit to involving too much, which will stress the people around them resulting in unsatisfactory performance.

However, inspiration motivation is not the selection of the project leader to motivate employees when there is no significant correlation between the inspiration motivations to the success of the project. According to managers, they focus to build their image rather than the future picture of the project. The project would be failed by many uncertainty reasons, drawing the perfect project future would put them under pressure to achieve commitment to employees.

\section{Suggestions for Future Research and Limitation}

This research has shown what project leaders focus on in the implementation process to lead to a successful project, including emotional intelligence, transformational leadership, and organizational commitment. However, the evaluation of their employees is also very necessary. If further research can be done with the sample of employees and the project leaders, dividing into 2 groups to compare their views on the project in terms of evaluating the role of emotional intelligence and transformational leadership.

\section{References}

Aga, D. A., Noorderhaven, N., \& Vallejo, B. (2016). Transformational leadership and project success: The mediating role of team-building. International Journal of Project Management, 34(5), 806-818. https://doi.org/10.1016/j.ijproman.2016.02.012

Andersen, E. S., Arne Jessen, S., Birchall, D., \& Money, A. H. (2006). Exploring project success. Baltic Journal of Management, 1(2), 127-147.

Angus, G. Y., Bowers, J. A., \&Flett, P. D. (2005). Developing a value-centred proposal for assessing project success. International Journal of Project Management, 23(6), 428-436. https://doi.org/10.1016/j.ijproman.2005.01.008

Asare, J. (2016). Emotional Intelligence as an Essential Factor for the Successful Management and Financial Administration of Projects and Programs. American Journal of Industrial and Business Management, 6(4), 418-431.

Ashkanasy, N. M., Daus, C. S., \&Härtel, C. E. (2002). Diversity and emotion: The new frontiers in organizational behavior research. Journal of Management, 28(3), 307-338. https://doi.org/10.1016/S0149-2063(02)00130-7

Avolio, B. J., Walumbwa, F. O., \& Weber, T. J. (2009). Leadership: Current theories, research, and future directions. Annual Review of Psychology, 60, 421-449. https://doi.org/10.1146/annurev.psych.60.110707.163621

Avots, I. (1969). Why does project management fail? California Management Review, 12(1), 77-82. https://doi.org/10.2307/41164208

Avolio, B. J., \& Bass, B. M. (eds.). (1994). Improving organizational effectiveness through transformational leadership. Thousand Oaks, CA: Sage Publications.

Atwater, L., Carmeli, A., \& Levi, A. (2011). How leadership enhances employees' knowledge sharing: the intervening roles of relational and organizational identification. The Journal of Technology Transfer, 36(3), 257-274.

Caroline, N., Harriet, K., \& Anne, N. (2016). Top management commitment for successful small and medium-enterprises (SMEs): a hoax or a reality? European Scientific Journal, 12(4). http://dx.doi.org/10.19044/esj.2016.v12n4p259

Aouad, G., El-Saboni, M., \& Sabouni, A. (2009). Electronic communication systems effects on the success of construction projects in United Arab Emirates. Advanced Engineering Informatics, 23(1),130-138. https://doi.org/10.1016/j.aei.2008.07.005

Arshad, N., Ehsan, N., Gulzar, M., Hafeez, M., \& Mirza, E. (2012). The impact of employees' project commitment and its effect on IT industry of Pakistan. Procedia Technology, 1, 258261. https://doi.org/10.1016/j.protcy.2012.02.052

Ashkanasy, N. M., Chang, A., Mazur, A., \& Pisarski, A. (2014). Rating defence major project success: The role of personal attributes and stakeholder relationships. International Journal of Project Management, 32(6), 944-957. https://doi.org/10.1016/j.ijproman.2013.10.018 
Baccarini, D. (1999). The logical framework method for defining project success. Project Management Journal, 30(4), 25-32. https://doi.org/10.1177/875697289903000405

Bakhsheshi, H. A., \& Nejad, R. S. (2011). Impact of project managers' personalities on project success in four types of project. In International Conference on Construction and Project Management, 15(2), 181-186.

Balogun, J., \& Johnson, G. (2004). Organizational restructuring and middle manager sense making. Academy of Management Journal, 47(4), 523-549. https://doi.org/10.5465/20159600

Barbuto, J. E., \& Burbach, M. E. (2006). The emotional intelligence of transformational leaders: A field study of elected officials. The Journal of Social Psychology, 146(1), 51-64. https://doi.org/10.3200/SOCP.146.1.51-64

Barling, J. (2014). The science of leadership: Lessons from research for organizational leaders. Oxford, UK: Oxford University Press.

Barling, J., Kelloway, K. E., \& Slater, F., (2000). Transformational leadership and emotional intelligence: An exploratory study. Leadership \& Organization Development Journal, 21(3), 157-161. https://doi.org/10.1108/01437730010325040

Bass, B. M. (1985). Leadership and performance beyond expectations. New York, NY: Collier Macmillan.

Bentler, P. M., \& Hu, L. T. (1999). Cutoff criteria for fit indexes in covariance structure analysis: Conventional criteria versus new alternatives. Structural Equation Modeling, 6(1), 1-55. https://doi.org/10.1080/10705519909540118

Bryde, D. (2008). Perceptions of the impact of project sponsorship practices on project success. International Journal of Project Management, 26(8), 800-809. https://doi.org/10.1016/j.ijproman.2007.12.001

Butler, C. J. (2005). The relationship between emotional intelligence and transformational leadership behavior in construction industry leaders. Boulder, CO: University of Colorado Boulder. https://doi.org/10.1016/j.leaqua.2006.02.007

Brown, D. J., \& Lord, R. G. (2001). Leadership, values, and subordinate self-concepts. The Leadership Quarterly, 12(2), 133-152. https://doi.org/10.1016/S1048-9843(01)00072-8

Bakker, H. L., Mooi, H. G., \& Suprapto, M. (2015). Relational factors in owner-contractor collaboration: The mediating role of team working. International Journal of Project Management, 33(6), 1347-1363. https://doi.org/10.1016/j.ijproman.2015.03.015

Cartwright, S., \& Lindebaum, D. (2010). A critical examination of the relationship between emotional intelligence and transformational leadership. Journal of Management Studies, 47(7), 1317-1342. https://doi.org/10.1111/j.14676486.2010.00933.x

Chan, A. P. (2001). Time-cost relationship of public sector projects in Malaysia. International Journal of Project Management, 19(4), 223-229. https://doi.org/10.1016/S02637863(99)00072-1

Clarke, N. (2010). Emotional intelligence abilities and their relationships with team processes. Team Performance Management: An International Journal, 16(1/2), 6-32.

Dulewicz, V., \& Higgs, M. (2005). Assessing leadership styles and organisational context. Journal of Managerial Psychology, 20(2), 105-123.
Dvir, D. O. V., Malach-Pines, A., \& Sadeh, A. (2006). Projects and project managers: The relationship between project managers' personality, project types, and project success. Project Management Journal, 37(5), 36-48. https://doi.org/10.1177/875697280603700505

Dvir, D., Levy, O., Maltz, A. C., \& Shenhar, A. J. (2001). Project success: a multidimensional strategic concept. Long Range Planning, 34(6), 699-725. https://doi.org/10.1016/S00246301(01)00097-8

Dvir, D., Lipovetsky, S., Lechler, T., Shenhar, A. J., \& Tishler, A. (2002). Refining the search for project success factors: a multivariate, typological approach. $R \& D$ Management, 32(2), 111-126. https://doi.org/10.1111/1467-9310.00244

De Gilder, D., Ellemers, N., \& Haslam, S. A. (2004). Motivating individuals and groups at work: A social identity perspective on leadership and group performance. Academy of Management Review, 29(3), 459-478. https://doi.org/10.5465/amr.2004.13670967

Erez, M., Locke, E. A., \& Latham, G. P. (1988). The determinants of goal commitment. Academy of Management Review, 13(1), 23-39. https://doi.org/10.5465/amr.1988.4306771

Fowler, J. J., \& Horan, P. (2007). Are information systems' success and failure factors related? An exploratory study. Journal of Organizational and End User Computing, 19(2), 1-22.

Frimpong, S. K., Hongyi, X., \& Nubuor, S. A. (2014). The Impact of Transformational Leadership Style on Project Success: An Empirical Study of Banking Projects in Ghana. International Journal of ICT and Management, 2(1), 85-95.

Ghazinejad, M., Hussein, B., \& Zidane, Y. (2018). Impact of trust, commitment, and openness on research project performance: Case study in a research institute. Social Sciences, 7(2), 22. https://doi.org/10.3390/socsci7020022

Goleman, D. (1996). Emotional intelligence. Why it can matter more than IQ. Learning, 24(6), 49-50.

Gundersen, G., Hellesøy, B. T., \& Raeder, S. (2012). Leading international project teams: The effectiveness of transformational leadership in dynamic work environments. Journal of Leadership \& Organizational Studies, 19(1), 46-57. https://doi.org/10.1177/1548051811429573

Hair, J. F, Hult, G., Ringle, C., \& Sarstedt, M. (2017). A primer on partial least squares structural equation modeling (PLS-SEM) (2nd ed.). Thousand Oaks, CA: Sage.

Hair, J. F., Risher, J. J., Sarstedt, M., \& Ringle, C. M. (2019). When to use and how to report the results of PLSSEM. European Business Review, 31(1), 2-24.

Henseler, J., Ringle, C. M., \& Sinkovics, R. R. (2009). The use of partial least squares path modeling in international marketing. In New challenges to international marketing (pp. 277-319). Bingley, UK: Emerald Group Publishing Limited.

Henseler, J., Hubona, G., \& Ray, P. (2016). Using PLS path modeling in new technology research: updated guidelines. Industrial Management \& Data Systems, 116(1), 2-20.

Henseler, J., Ringle, C. M., \& Sarstedt, M. (2015). A new criterion for assessing discriminant validity in variance-based structural equation modeling. Journal of the Academy of Marketing Science, 43(1), 115-135.

Henseler, J. (2017). Bridging Design and Behavioral Research with Variance-Based Structural Equation Modeling. Journal of 
Advertising, $46(1)$ https://doi.org/10.1080/00913367.2017.1281780

178-192.

Huang, T. C., \& Wang, Y. S. (2009). The relationship of transformational leadership with group cohesiveness and emotional intelligence. Social Behavior and Personality, 37(3), 379-392.

https://doi.org/10.2224/sbp.2009.37.3.379

Huang, C. F., Wu, K. S., \& Yang, L. R. (2011). The association among project manager's leadership style, teamwork and project success. International Journal of Project Management, 29(3), 258-267. https://doi.org/10.1016/j.ijproman.2010.03.006

Iqbal, S. M. J., Khan, S., \& Sang, L. C. (2015). Importance of transformational leadership in project success: A theoretical framework. Topical Economics (Актуальніпроблемиекономіки), (1), 67-76.

Jordan, P. J., \& Lawrence, S. A. (2009). Emotional intelligence in teams: Development and initial validation of the short version of the Workgroup Emotional Intelligence Profile (WEIPS). Journal of Management \& Organization, 15(4), 452469. https://doi.org/10.1017/S1833367200002546

Jovanovic, P., Mihic, M., \& Mitrovic, Z., Obradovic, V., Petrovic, D., (2013). Project managers' emotional intelligence-a ticket to success. Procedia-Social and Behavioral Sciences, 74, 274284. https://doi.org/10.1016/j.sbspro.2013.03.034

Jugdev, K., \& Müller, R. (2005). A retrospective look at our evolving understanding of project success. Project Management Journal, 36(4), 19-31. https://doi.org/10.1177/875697280503600403

Khang, D. B., \& Moe, T. L. (2008). Success criteria and factors for international development projects: A life cycle based framework. Project Management Journal, 39(1), 72-84. https://doi.org/10.1002/pmj.20034

Korzaan, M. L. (2009). The influence of commitment to project objectives in information technology (IT) projects. Review of Business Information Systems, 13(4), 89-98.

Kwak, Y. H. (2005). Brief history of project management. In E. G. Carayannis, Y. H. Kwak, \& F. T. Anbari (eds), The story of managing projects. Westport, CT: Praeger Publishers/Greenwood Publishing Group.

Kaplan, R. S., \& Norton, D. P. (2007). Using the balanced scorecard as a strategic management system. Harvard Business Review, (July-August). Retrieved from https://hbr.org/2007/07/using-the-balanced-scorecard-as-astrategic-management-system

Khanzada, B., \& Naeem, S. (2017). Impact of transformational leadership in attainment of project success: the mediating role of job satisfaction. International Journal of Business and Social Science, 8(9), 168-177.

Kouzes, J. M., \& Posner, B. Z. (2002). The leadership practices inventory: Theory and evidence behind the five practices of exemplary leaders. The Leadership Challenge,

Appendix0512BP. Retrieved November 10, 2019 from: http://www.leadershipchallenge.com/UserFiles/lc_jb_appendix .pdf

Lara, T. (2011). Comparing The Emotional Intelligence, Personal Traits, And Work Impacts Of Performing Versus HighPerforming Middle Managers. Malibu, CA: Pepperdine
University.

Law, K. S., \& Wong, C. S. (2002). The effects of leader and follower emotional intelligence on performance and attitude: An exploratory study. The Leadership Quarterly, 13(3), 243274. https://doi.org/10.1016/S1048-9843(02)00099-1

Martin, R., \& Epitropaki, O. (2005). The moderating role of individual differences in the relation between transformational/transactional leadership perceptions and organizational identification. The Leadership Quarterly, 16(4), 569-589. https://doi.org/10.1016/j.leaqua.2005.06.005

Lee, J. Y. (2018). The Effects of Job Characteristics on the Team Creativity of Distribution Companies: Moderating Effects of Transformational Leadership. Journal of Asian Finance, Economics and Business, 5(4), 161-172. http://doi.org/10.13106/jafeb.2018.vol5.no4.161

Liu, W., Zhu, R., \& Yang, Y. (2010). I warn you because I like you: Voice behavior, employee identifications, and transformational leadership. The Leadership Quarterly, 21(1), 189-202. https://doi.org/10.1016/j.leaqua.2009.10.014

Mayer, J. D., \& Salovey, P. (1997). What is emotional intelligence? In P. Salovey, \& D. Sluyter (eds.), Emotional development and emotional intelligence: educational implications (pp. 3-34). New York, NY: Basic Books.

Mir, F. A., \& Pinnington, A. H. (2014). Exploring the value of project management: linking project management performance and project success. International Journal of Project Management, 32(2), 202-217. https://doi.org/10.1016/j.ijproman.2013.05.012

Mowday, R. T., Porter, L. W., \& Steers, R. M. (1979). The measurement of organizational commitment. Journal of Vocational Behavior, 14(2), 224-247. https://doi.org/10.1016/0001-8791(79)90072-1

Müller, R., \& Rodney Turner, J. (2010). Attitudes and leadership competences for project success. Baltic Journal of Management, 5(3), 307-329.

Müller, R., \& Turner, R. (2007). The influence of project managers on project success criteria and project success by type of project. European Management Journal, 25(4), 298309. https://doi.org/10.1016/j.emj.2007.06.003

Mayer, J. D., \& Salovey, P. (1990). Emotional intelligence. Imagination, Cognition and Personality, 9(3), 185-211. https://doi.org/10.2190/DUGG-P24E-52WK-6CDG

Ndiritu, C. M. N. (2015). Influence of Total Quality Management practices on performance of small and medium enterprises: $A$ case of youth groups projects in Kajiado North sub county, Kajiado county, Kenya (Unpublished Master's Thesis). University of Nairobi.

Nitzl, C. (2016). The use of partial least squares structural equation modelling (PLS-SEM) in management accounting research: Directions for future theory development. Journal of Accounting Literature, 37, 19-35. https://doi.org/10.1016/j.acclit.2016.09.003

Pham, V. Q., Nguyen, B. K. Q., Tu, V. B., Pham, H. T. T., \& LE, T. Q. (2019). Critical Success Factors of Project Management: The Case of Construction Related Projects in Vietnam. Journal of Asian Finance, Economics and 
Business, 6(2), 223-230.

https://doi.org/10.13106/jafeb.2019.vol6.no2.223

Pinto, J. K., \& Prescott, J. E. (1988). Variations in critical success factors over the stages in the project life cycle. Journal of Management, 14(1), 5-18. https://doi.org/10.1177/014920638801400102

Pinto, J. K., \& Slevin, D. P. (1987). Critical factors in successful project implementation. IEEE Transactions on Engineering Management, (1), 22-27.

DOI: 10.1109/TEM.1987.6498856

Scott-Young, C., \& Samson, D. (2008). Project success and project team management: Evidence from capital projects in the process industries. Journal of Operations Management, 26(6), 749-766. https://doi.org/10.1016/j.jom.2007.10.006

Shenhar, A. J., \& Wideman, R. M. (1996). Improving PM: Linking success criteria to project type. In the Southern Alberta Chpater, Project Management Institute, Symposium "Creating
Canadian Advantage through Project Management”. Calgary, Canada.

Sohmen, V. S. (2013). Leadership and teamwork: Two sides of the same coin. Journal of IT and Economic Development, 4(2), 118.

Srića, V. (2008, May). Social intelligence and project leadership. In The Global Management and IT Research Conference, New York, USA.

Stefanovic, J. V. (2008). An integrative strategic approach to project management and a new maturity model $(\mathrm{PhD}$ Dissertation). Stevens Institute of Technology. Hoboken, New Jersey.

Suong, H. T. T., Thanh, D. D., \& Dao, T. T. X. (2019). The Impact of Leadership Styles on the Engagement of Cadres, Lecturers and Staff at Public Universities-Evidence from Vietnam. Journal of Asian Finance, Economics and Business, 6(1), 273-280.

http://doi.org/10.13106/jafeb.2019.vol6.no1.273 